\title{
Antibacterial effect of clove (Eugenia aromaticum) oil extracted from clove cigarettes towards Streptococcus mutans
}

\author{
Ahmad Alif Wazir bin Jumali*, Mieke Hermiawati Satari*, Warta Dewi* \\ *Department of Oral Biology Faculty Of Dentistry Universitas Padjadjaran, Indonesia
}

\begin{abstract}
Streptococcus mutans is a commensal bacteria of the oral cavity, particularly found in dental plaque attached to the tooth surface, and can also found in the saliva, buccal mucosa, tongue, and the gingival sulcus. Clove cigarette contains the clove oil used worldwide as a herbal remedy for a variety of health disorders due to its antibacterial, antifungal, and antiviral properties. The purpose of this study was to determined the antibacterial effect of the clove oil contained in the clove cigarette towards Streptococcus mutans as a cariogenic bacteria. The research was an experimental laboratory, which tested the sensitivity of the Streptococcus mutans bacteria taken from the saliva of 10 clove cigarette smokers towards the clove oil extract of the clove cigarette in-vitro by using the Kirby-Bauer method. The study showed that the clove oil extract of the clove cigarette which contained eugenol has antibacterial towards the growth of Streptococcus mutans, and there was a difference of the antibacterial activity between clove oil extracted from minced and combusted clove cigarette. The conclusion of this study was the clove oil extracted from minced clove cigarette had a better antibacterial effect than the combusted clove cigarette.
\end{abstract}

Keywords: Antibacterial effect, clove oil, Streptococcus mutans, clove cigarette

\section{INTRODUCTION}

Nowadays, smoking has become the worldwide health concerning problem. The smoking habit has a high tendency for the respiratory and gastrointestinal epithelium cancer development. There is a possibility that cigarette smoke may directly affect the commensal flora of the oral cavity. Smokers also have tendencies to develop gingival infections. These infections occurred as a result of complex interaction of the host, bacteria, and the short- and long-term effects of cigarette smoke. ${ }^{1}$
There are two types of cigarettes, a filtered-cigarette, and a non-filtered cigarette. The only difference between a filtered and nonfiltered cigarettes is that non-filtered cigarettes allow slightly higher levels of nicotine into the smoker's system. ${ }^{2}$

Furthermore, in Indonesia, there are several types of cigarettes available in the market. One of them is the clove cigarettes. Clove cigarette which is also known as kretek, produced in Indonesia and distributed worldwide, and often mistakenly thought as a safe smoking alternative because the clove oil contained in the cigarettes is well known 
as a herbal remedy for various health disorders including toothaches, indigestion, cough, asthma, headache, stress, and blood impurities. ${ }^{3}$

In the research conducted by Keene and Johnson, ${ }^{4}$ the amount of nicotine in cigarettes may affected the bacteria growth because of the high level of nicotine volume in the saliva of smokeless tobacco users. Thus, the smokeless tobacco use could stimulate the growth of Streptococcus mutans and increased risk for dental caries.

The health benefits of clove oil attributed to its antibacterial, antifungal, and antiviral properties. $^{3}$ Clove oil has the ability to inhibit the growth of Streptococcus mutans by disrupting bacterial cell membrane, thus increasing the permeability of the membrane and causing bacteria to lysis. ${ }^{5}$

Clove cigarettes are composed of a mixture of tobacco $(60-80 \%)$, ground clove buds (20-40\%), clove oil, and other additives. ${ }^{6}$ Clove cigarettes are available with or without filters, and usually machine rolled in the white, brown, or black paper, with pungently sweet odor and taste (Malson et al., 2002). Clove cigarettes deliver higher tar content than most cigarettes, ranging from 34$65 \mathrm{mg}$; nicotine ranging from $1.9-2.6 \mathrm{mg}$; and carbon monoxide from $18-28 \mathrm{mg}$ per cigarette. ${ }^{3,7}$ The high deliveries of tar probably caused by the combination of four factors: the nature of Indonesian tobacco as the cigarette compound; the high weight of the cigarettes; the number of puffs required to smokes the cigarette; and the tar residues left by the clove bud. ${ }^{3}$ Much of the smoke derived from a clove cigarette contains a simple distillation of clove oil, without oxidation of the elements. Distilled clove oil composition obtained from the combustion of $100 \%$ clove cigarette, consists primarily of eugenol and related compounds which also identified in the natural clove oil. ${ }^{3}$

According to the research conducted by Walsh and Tsang, ${ }^{8}$ smoking will create the low oxygen environment and cause salivary dysfunction, because the effects of nicotine on salivary gland flow that will cause a reduction in the $\mathrm{pH}$ value of the oral cavity. These conditions are a favourable parameter for Streptococcus mutans growth.

Streptococcus mutans is a gram-positive bacteria live in the oral cavity. It can thrive in the temperature ranging from $18-40^{\circ} \mathrm{C}$. It metabolizes different kinds of carbohydrates, creating an acidic environment in the oral cavity. Thus, these acidic environments in the mouth that will cause the tooth decay. This is the leading cause of dental caries worldwide. Streptococcus mutans is considered to be the most cariogenic of all of the oral Streptococci. ${ }^{9}$ Streptococcus mutans would cause dental caries and eventually lead to the tooth decay and the tooth loss. The decayed tooth will lose its function and would cause multiple infections such as periapical abscess thus needs to be extracted. Tooth decay will cause mastication problem and psychological problems such as low self-esteem and poor socialization. Tooth decay is one of the most common infectious diseases in humans. 10

\section{METHODS}

The research method was an experimental laboratory to determine the antibacterial effect of the clove oil of the clove cigarette towards the growth of Streptococcus mutans. The population of this research was clove cigarettes from all brand. The sample of this research was taken by a random sampling method of the population. Materials used In this research were clove cigarettes, clove oil (as the control group), Streptococcus mutans bacteria isolated from saliva, Trypticase Yeast Cysteine Sucrose Bacitracin (TYCSB) agar, and blood agar with sugar addition.

\section{RESULTS}

The saliva sample taken from smokers were cultured on TYCSB agar plate and incubated in candle jar to create a facultative anaerobes environment at $37^{\circ} \mathrm{C}$ for 72 hours. After 72 hours, the TYCSB agar plate showed a tiny white, crystallike cauliflower shape colonies attached firmly to the medium. The result of such reactions was a characteristic indicated that the colony was Streptococcus mutans. This reaction was a result of the Bacitracin antibiotic which added to the medium that suppresses the growth of most species besides Streptococcus mutans to grow (Figure 1). ${ }^{11}$

Figure 2 showed the result of microscopic examination of the colonies with gram staining 
characterized the cocci-shaped gram-positive bacteria with the chain formation.

The assessment of the antibacterial activity of clove oil towards Streptococcus mutans was performed with the Kirby-Bauer agar diffusion

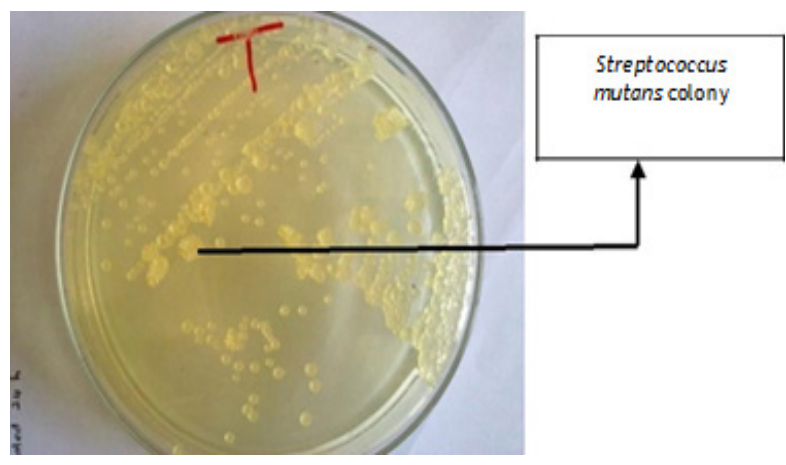

Figure 1. Streptococcus mutans colony on TYCSB agar plate

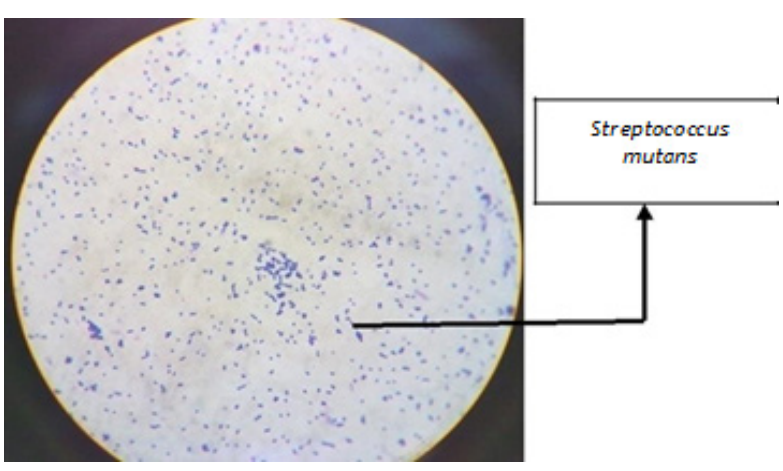

Figure 2. Microscopic views of Streptococcus mutans

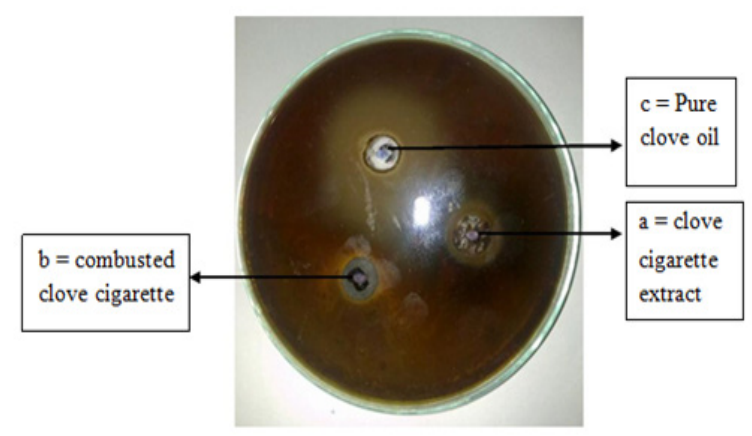

Figure 3. Antibacterial inhibitory zone of clovecigarette-extracted clove oil and pure clove oil towards Streptococcus mutans method. The bacteria inhibitory zone around the hole filled with a mixture of clove cigarette and pure clove oil after incubated in the facultative anaerobic environment at $37^{\circ}$ Celcius for 24 hours were presented in Figure 3 . The measurement results of the clove oil antibacterial inhibitory zone towards Streptococcus mutans in 5 samples tested were shown in Table 1.

Based on the results shown in Table 1, there were differences in the inhibitory zone of each sample. The average inhibitory area of the clove cigarette-extracted clove oil was $3.23 \mathrm{~mm}$, while the combusted clove cigarette-clove oil showed the average value was $1.89 \mathrm{~mm}$. The control group (pure

Table 1 The result of the inhibition zone measurement of clove oil extract toward Streptococcus mutans

\begin{tabular}{ccccc}
\hline Sample & Repetition & \multicolumn{3}{c}{$\begin{array}{c}\text { Inhibitory zone } \\
(\mathrm{mm})\end{array}$} \\
\hline \multirow{2}{*}{$\mathrm{A}$} & 1 & $\mathrm{a}$ & $\mathrm{b}$ & $\mathrm{c}$ \\
& 2.95 & 1.20 & 11.36 \\
$\mathrm{~B}$ & 1 & 2.56 & 1.29 & 10.27 \\
& 2 & 2.85 & 1.25 & 8.05 \\
$\mathrm{C}$ & 1 & 3.97 & 1.53 & 12.73 \\
& 2 & 3.65 & 1.40 & 9.31 \\
$\mathrm{D}$ & 1 & 2.49 & 1.25 & 12.69 \\
& 2 & 2.64 & 2.57 & 9.90 \\
$\mathrm{E}$ & 1 & 3.22 & 1.50 & 9.70 \\
& 2 & 3.26 & 1.75 & 10.26 \\
\hline Average & & 3.23 & 1.89 & 10.39 \\
\hline
\end{tabular}

Note: $\mathrm{a}=$ clove cigarette extract; $\mathrm{b}=$ combusted clove cigarette; $c=$ pure clove oil

Table 2. Varians analysis

\begin{tabular}{cccc}
\hline & Variables & $\begin{array}{c}\text { Mean } \\
\text { Difference }\end{array}$ & Significant \\
\hline a & B & 1.57700 & 0.001 \\
& C & -7.33120 & 0.000 \\
b & A & -1.57700 & 0.001 \\
& C & -8.90820 & 0.000 \\
C & A & 7.33120 & 0.000 \\
& B & 8.90820 & 0.000 \\
\hline
\end{tabular}

Table 3. Comparison test between variables

\begin{tabular}{cccccc}
\hline Source of Variation & SS & df & MS & F Value & F Table \\
\hline Between Groups & 451.961 & 2 & 225.982 & 241.840 & 3.34 \\
Within Groups & 25.230 & 27 & 0.934 & & \\
\hline Total & $\mathbf{4 7 7 . 1 9 4}$ & & & & \\
\hline
\end{tabular}


clove oil) showed the average value of $10.39 \mathrm{~mm}$.

According to Sudjana, 12 the results of the statistical analysis with 95\% confidence level (a $=0.05$ ) showed significant results because the countable $F$ value was greater than the $F$ table as shown in Table 2. Since the test statistic ( $F$ value) was higher than the critical value ( $\mathrm{F}$ table), there were significant differences in the antibacterial effect of clove oil extract extracted from clove cigarette and pure clove oil towards Streptococcus mutans.

If the result of a comparison test between variables showed the significant value lower than 0.05 (Sig<0.05), suggested significant differences.

Table 3 showed that significant differences between variable $a-b$, variable $a-c$, and variable b-c. Based on data in Table 1, Table 2. and Table 3 , were concluded that the clove oil extracted from both clove cigarette and combusted clove cigarette have antibacterial activity towards the growth of Streptococcus mutans.

\section{DISCUSSION}

According to Table 1, Streptococcus mutans were less found in the mixture of clove oil extracted from clove cigarette and combusted clove cigarette compare to the pure clove oil. This finding was caused by the mixture of nicotine and other compound and less concentration of clove oil in the clove cigarette. Furthermore, in the combusted clove cigarette, the effect of eugenol was less due to the evaporation eugenol compound during combustion.

In Table 2 and 3 presented a difference between clove oil extract, combusted clove cigarette, and pure clove oil. This finding was caused by the amount of the clove oil contained in the extract. The higher concentration of clove oil, the higher antibacterial effect towards the growth of Streptococcus mutans. The low antibacterial effect shown from clove cigarette extract means that only less concentration of clove oil was found in the clove cigarette.

Clove oil consists of eugenol which is the phenol group. This component is a highly active antibacterial agent. ${ }^{13}$ The mechanism of antibacterial activity of eugenol towards bacteria causes by the interaction of eugenol on the bacterial cell membrane by increasing the permeability of the membrane.5 Eugenol damages the membrane of bacteria by causing protein and lipid breakage. This action is the result of its hydrophobicity characteristic which enables eugenol to breaks the lipids of bacteria cell membrane, disturbing the cell structure, and rendering them to becomes more permeable. ${ }^{14}$

According to the results obtained in Table 1 , there were variations in the inhibitory zone diameters of each sample. This finding was probably due to the mechanism by bacteria to resist the bactericidal and bacteriostatic action of the antibacterial agent. One of the mechanisms is antibiotic efflux pumps. Microorganisms have adapted antibiotic efflux pumps from their original purpose which is to expel waste products or toxins to a very efficient means of antibiotic resistance. More than 50 such efflux systems (multidrug efflux pumps, cytoplasmic membrane efflux proteins) have been described operating in many microorganisms such as Escherichia coli, Pseudomonas aeruginosa, Enterococci, Staphylococci, and Streptococci. ${ }^{15}$

Smoking creates anaerobiosis within the oral cavity, and the low oxygen environment favours the growth of Streptococcus mutans. There are two additional components involved in the impact of smoking on dental caries. The first is salivary dysfunction which will cause a decreasing salivary flow. This is the result of the pharmacological effects of nicotine on salivary gland flow. Reduced flow linked with reduced $\mathrm{pH}$ value, which is also a favourable parameter for Streptococcus mutans growth. The second factor is the direct effect of nicotine in the salivary milieu on Streptococcus mutans. There was some evidence that nicotine itself can directly affect the growth of Streptococcus mutans, with concentrations of nicotine of 0.1-1.0 mmol/L was able to stimulate growth, although higher concentrations will affected adversely. ${ }^{8}$

Smokes derived from a clove cigarette was a simple distillation of clove oil, without oxidation of the compounds. The composition of distilled clove oil, as obtained by the combustion of a $100 \%$ clove cigarette, consists primarily of eugenol and related compounds which are also identified in natural clove oil. ${ }^{3}$

There are still controversial issues of the use of clove cigarette. In this research, the in- 
vitro test showed that the clove oil extracted from the clove cigarette inhibited the growth of Streptococcus mutans, but the cigarette smoke and nicotine in the clove cigarette can eventually increase the growth of Streptococcus mutans.

\section{CONCLUSION}

The conclusion of this study was the clove oil extracted from minced clove cigarette had a better antibacterial effect than the combusted clove cigarette.

\section{REFERENCES}

1. ErtelA, EngR, SmithSM. The differential effect of cigarette smoke on the growth of bacteria found in humans. Chest. 1991 Sep;100(3):628-30.

2. Healthfully [homepage on internet]. St. Monica, CA: Miley E. 2010. Filtered vs. Unfiltered Cigarettes. [cited 2011 Jan]; [about 1 screen]. Available from: https:// healthfully.com/filtered-vs-unfilteredcigarettes-6501299.html

3. Guidotti TL, Laing L, Prakash UB. Clove cigarettes : the basis for concern regarding health effects. West J Med. 1989 Aug;151(2):220-8.

4. Keene K, Johnson RB. The effect of nicotine on growth of Streptococcus mutans. Miss Dent Assoc J. 1999;55(4):38-9.

5. Devi KP, Nisha SA, Sakthivel R, Pandian SK. Eugenol (an essential oil of clove) acts as an antibacterial agent against Salmonella typhi by disrupting the cellular membrane. $J$ Ethnopharmacol. 2010 Jul 6;130(1):107-15.

6. Martin T. 2010. Are Clove Cigarettes a Safe Smoking Alternative? [cited 2011 Jan]; [about 1 screen]. Available from: https://about. com/health-disease-and-condition.html

7. Malson JL, Lee EM, Murty R, Moolchan ET, Pickworth WB. Clove Cigarette Smoking: Biochemical, Physiological, and Subjective Effects. Pharmacol Biochem Behav. 2003 Feb;74(3):739-45.

8. Walsh LJ, Tsang AK. Chairside Testing for Cariogenic Bacteria: Current Concept and Clinical Strategies. J Minim Interv Dent. 2008;1(2):126-51.

9. Genome News Network [homepage on internet]. Rockville: Winstead ER. 2002. Fighting Cavities - Bacterium that causes tooth decay, S. mutans, is sequenced. [cited 2011 Mar]; [about 1 screen]. Available from: http: / / www.genomenewsnetwork.org / articles/10_02/s_mutans.shtml

10. Casamassimo PS. Maternal oral health. Dent Clin North Am. 2001 Jul 01;45(3):469-78.

11. Wan AK, Seow WK, Walsh LJ, Bird PS. Comparison of five selective media for the growth and enumeration of Streptococcus mutans. Aust Dent J. 2002 Mar;47(1):21-6.

12. Sudjana A. Metoda Statistika. 6th ed. Bandung: Tarsito; 2005. p. 299-302.

13. Pelczar MJ, Chan ECS, Krieg NR. Control of microorganisms, the control of microorganisms by physical agents. In: Microbiology. New York: McGraw-Hill International; 1988. p. 469-509.

14. Oyedemi SO, Okoh Al, Mabinya LV, Pirochenva $\mathrm{G}$, Afolayan AJ. The proposed mechanism of bactericidal action of eugenol, a-terpineol and $\gamma$-terpinene against Listeria monocytogenes, Streptococcus pyogenes, Proteus vulgaris and Escherichia coli. Afr J Biotechnol. 2009 Apr 6;8(7):1280-6.

15. Nikaido H. Multiple antibiotic resistance and efflux. Curr Opin Microbiol. 1998 Oct;1(5):51623. 